\title{
Detecting and Distinguishing Ophiolite Rocks via Multispectral Remote Sensing in Bi'r Umq, Southeast Al Madinah Al Munawarrah, Saudi Arabia
}

\author{
Abdullah Omer Bamousa1, Saleh Seraj Matar², Mohamed Daoudi ${ }^{3 *}$ \\ ${ }^{1}$ Department of Geology, Faculty of Sciences, Taibah University, Madinah Mounawarah, Saudi Arabia \\ ${ }^{2}$ Remote Sensing Department, Saudi Geological Survey (SGS), Jeddah, Saudi Arabia \\ ${ }^{3}$ Department of Geography and GIS, Faculty of Arts and Humanities, King Abdulaziz University, Jeddah, Saudi Arabia \\ Email: abamousa@taibahu.edu.sa, a.o.bamousa@gmail.com, matar.ss@sgs.org.sa, `mdaoudi@kau.edu.sa, \\ *mdaoudi65@gmail.com
}

How to cite this paper: Bamousa, A.O., Matar, S.S. and Daoudi, M. (2021) Detecting and Distinguishing Ophiolite Rocks via Multispectral Remote Sensing in Bi'r Umq, Southeast Al Madinah Al Munawarrah, Saudi Arabia. International Journal of Geosciences, 12, 635-652.

https://doi.org/10.4236/ijg.2021.127036

Received: June 15, 2021

Accepted: July 26, 2021

Published: July 29, 2021

Copyright $\odot 2021$ by author(s) and Scientific Research Publishing Inc. This work is licensed under the Creative Commons Attribution International License (CC BY 4.0).

http://creativecommons.org/licenses/by/4.0/

(c) (i) Open Access

\begin{abstract}
The objective of this work is to show the contribution of multispectral remote sensing data to detect and distinguish the ophiolite rocks of Bi'r Umq and their geologic setting, southeast of Al Madinah Al Munawarrah in Saudi Arabia. This work includes detailed fieldwork lab studies, as well as processing operations, were performed on The Advanced Spaceborne Thermal Emission and Reflection Radiometer (ASTER 2006, 2007) and Satellite Pour L'Observation de la Terre SPOT 5 (2005) images of the study region. Among the processing techniques applied are band ratio, histogram stretching, the combination of spectral bands, image fusion. The techniques used permitted a clearly show that the ultramafic rocks are distinct from other rock units and contain important economic minerals. This research also illustrates the tectonic parameters and that the remains of the oceanic crust are exposed and juxtaposed to the rocks of the continental crust of the Arabian Shield. The results of the spatial data processing revealed a good positive concordance with the results of the field investigations.
\end{abstract}

\section{Keywords}

ASTER, SPOT, Ophiolite, Suture Zone, Metallogensis, Bi'r Umq

\section{Introduction}

The Precambrian ophiolites in Saudi Arabia include those associated with the 
Yanbu suture, Jabal Ess, Bi'r Umq suture, and the Jabal Thurwah, Al'ays, Hulyafah, Ruwah, Halaban, Nabitah, Hamdhah, and Al-Amar sutures [1]. They occur in discrete N-S and E-W trending sutures and/or faults zones that divide the Arabian Shield into terranes [2]. The E-W trending ophiolites, such as the Bi'r Umq, may represent the early stages of arc-trench, arc-arc, and/or arc-continent collisions prior to the final closure of the Mozambique Paleo-ocean. The N-S trending ophiolites may represent the terminal closure of the Mozambique Paleo-ocean and the collision of the east and the west Gondwana during the East African Origin [1]. The Bi'r Umq represents a remarkable area, where the remnants of oceanic crust are exposed and were juxtaposed with the rocks of the continental crust of the Arabian Shield. The Bi'r Umq is an E-W trending, dismembered ophiolite, which lacks sheeted dikes, comprises peridotite, gabbro, volcanic rocks, harzburgite, and is overlain by chert and tuff [2].

Prospecting for mining resources requires the mapping of the geological formations that make up the subsoil. This mapping involves the recognition and characterisation of a maximum number of outcrops likely to provide information on the nature of these formations [3]. Remote sensing techniques are among the most important and advanced sources to obtain data on the characteristics of land surfaces. The use of these data has always been considered as a source of information for geomorphological, geological studies and the discovery of new deposits [4] [5]. Based on visual analysis of the combination of spectral bands, several cartographic documents have been produced. The SPOT spatial images are a useful addition to fieldwork. Studies carried out in different areas throughout the world have also shown the capacity of ASTER images in the characterisation of natural surfaces [6].

Until now, some applications have illustrated the potential of the ASTER sensor to adequately represent minerals and lithological formations [7]-[14]. ASTER has renewed the mapping methods applied to mining investigation by providing additional information to geoscientists to determine the boundaries between different lithological types. Also, for the realization of geological documents, [8] [15] managed to make the spectral difference between minerals. In another study, the potential of the sensor in the geological mapping of an ultrabasic metamorphic complex was proven [6].

The ASTER sensor can provide complementary data for mapping mineralogical alteration, geothermal investigations, and lithologic discrimination [16]-[21]. The SPOT 5 satellite differs from previous SPOT satellites in that it provides higher resolution images from the high-resolution visible and near-infrared sensors, as the twin instruments acquire multispectral images with a resolution of $10 \mathrm{~m}$. The resolution of the panchromatic spectral bands (the entire visible range) is reduced from 10 to $5 \mathrm{~m}$. Only the mid-infrared channel retains a resolution of $20 \mathrm{~m}$. The imaging instruments have a special feature that allows for very high-resolution images. This new capability opens up new perspectives, particularly in the field of precision geology and reconnaissance [22]. 
In this framework, SPOT (2005) and ASTER $(2006,2007)$ images were chosen due to the number and position of the available spectral bands (Figure 1). The objective of this paper is to evaluate the contribution of these data through band ratios, spectral indices, when undertaking image combinations and multisource data fusion, to determine the occurrences of economic minerals, their host rocks, and their tectonic settings of the Bi'r Umq. This work integrates and reveals information on the reflectance and emissivity of objects in an arid region, as well as the analysis of the spectral potential of the data. This aim was accomplished by conducting fieldwork.

\section{Study Area}

The ophiolite sequence in the study area was named after a Bi'r Umq village that is located within the Al Madinah Al Munawarrah Province. It can be reached from Al Madinah via the Al Qaseem-Riyadh highway from about $200 \mathrm{~km}$ to the south of Al Madinah City. It is located east of Harrat Rahat and north of the Jabal Sayed Mine, between lat. $23^{\circ} 51^{\prime} 22^{\prime \prime} \mathrm{N}$. and lat. $24^{\circ} 01^{\prime} 57^{\prime \prime} \mathrm{N}$. and long $40^{\circ} 47^{\prime} 53^{\prime \prime} \mathrm{E}$. and long $41^{\circ} 13^{\prime} 18^{\prime \prime} \mathrm{E}$. The topographic of the study area shows that the ophiolites formed hills and mountains with moderate elevations from 800 to 1300 meters above sea level and are separated by a major NE-SW-trending wadi, the Wadi Ash Shubah, and its NW-SE-trending tributaries: Mahzul, Buraykah, Mundassah, and Kutayfah Nu'ayriah. Since the 80s, it has been established that the area is a part of an E-W trending suture, known as the Thurwah-Bi'r Umq suture [24]. It extends for more than $300 \mathrm{~km}$ from the Thurwah area in the west near the Red Sea coast to the Bi'r Umq area southeast of Madinah in the central part of the Arabian Shield (Figure 2(A)). The suture zone is one of the ophiolite-decorated sutures that divide the Arabian Shield into terranes, in which the Thurwah-Bi'r Umq suture separates the Hijaz from the Jeddah terranes.

\section{Geological Setting and Structure}

The rock assemblages in the study area are best described as part of a dismembered

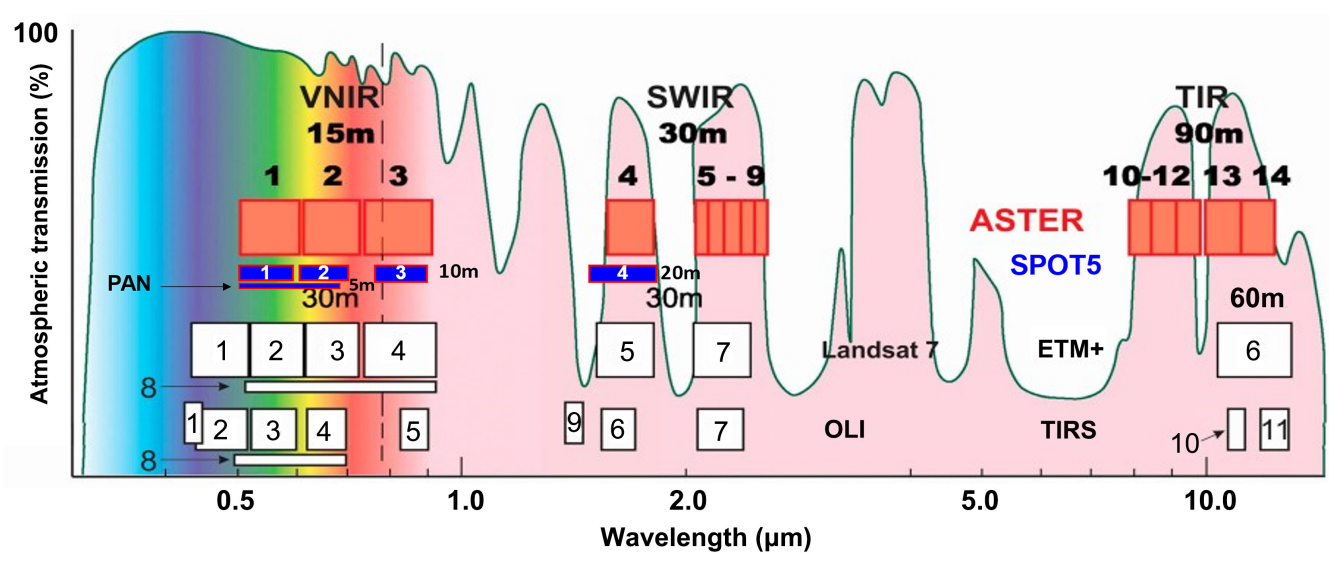

Figure 1. Electromagnetic spectrum comparing ASTER, SPOT5, LANDSAT 7-8 (ETM+ and OLI/TIRS) bands (modified after [16] [23]). 


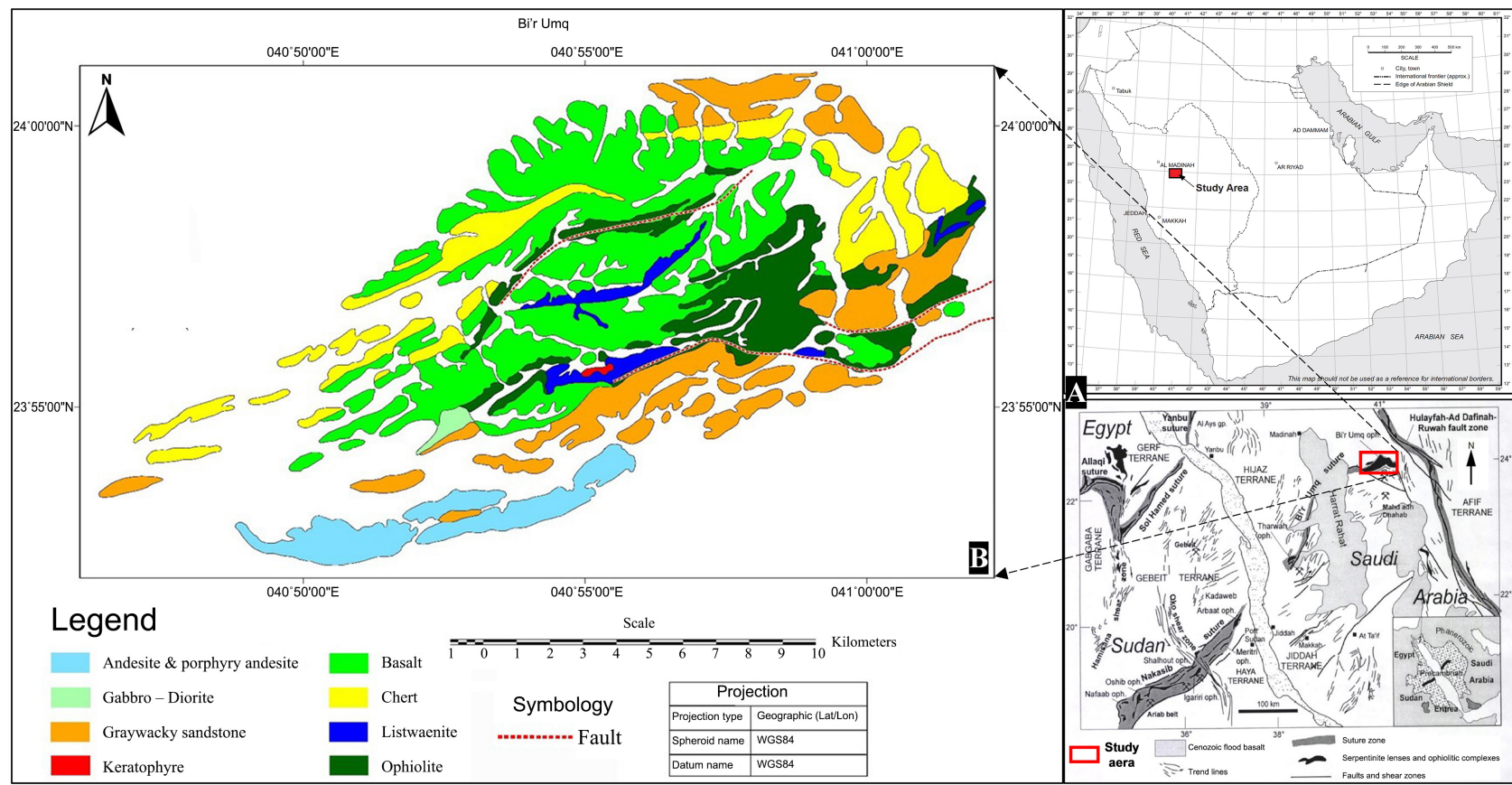

Figure 2. (A) Study area; (B) geologic map of the ophiolite complex of Bi'r Umq (adapted from [20]).

Alpine-type ophiolite suture [25] [26]. The ophiolite sequence is composed of layered gabbro and diorite, keratophyre, serpentinite, listwaenite, basalt, pillow lava, and chert (Figure 2(B)), reported to have developed in an island-arc setting within an oceanic-oceanic subduction zone [24] [27]-[32]. The chert beds are intercalated with thin-bedded pyroclastic tuffite and several beds of very fine-grained rhyolitic tuff. The whole sequence was intruded by microdiorite, diabase, andesite intrusive rocks, and numerous quartz veins.

The ophiolite complex in the study area underwent three tectonic deformational events [29]. It was found to be part of the D1 nappe structures that formed the overturned fault-related folds that trend ENE-WSW. The D1 structures were affected by the D2 structures, which formed the N-S trending folds. The third tectonic event, the D3, involved the formation of the NW-trending sinistral faults of the Najd system that cut all the D1 and the D2 structures. The later formed N-S trending quartz veins were found to cut the entire sequences in the region and the previously developed D1 to D3 structures. One ancient mine was found along a quartz vein, which hosts malachite and the iron oxides minerals.

\section{Materials and Methods}

The multi-temporal and multi-source data used in this research includes satellite images and a digital geological map. The technical characteristics of these different data sets are presented in Tables 1-3. The flowchart of the methodology is illustrated in Figure 3. Studies around the world have shown the capacity and potential of ASTER images to adequately represent geological formations and minerals. ASTER was chosen because of the number and position of the available 


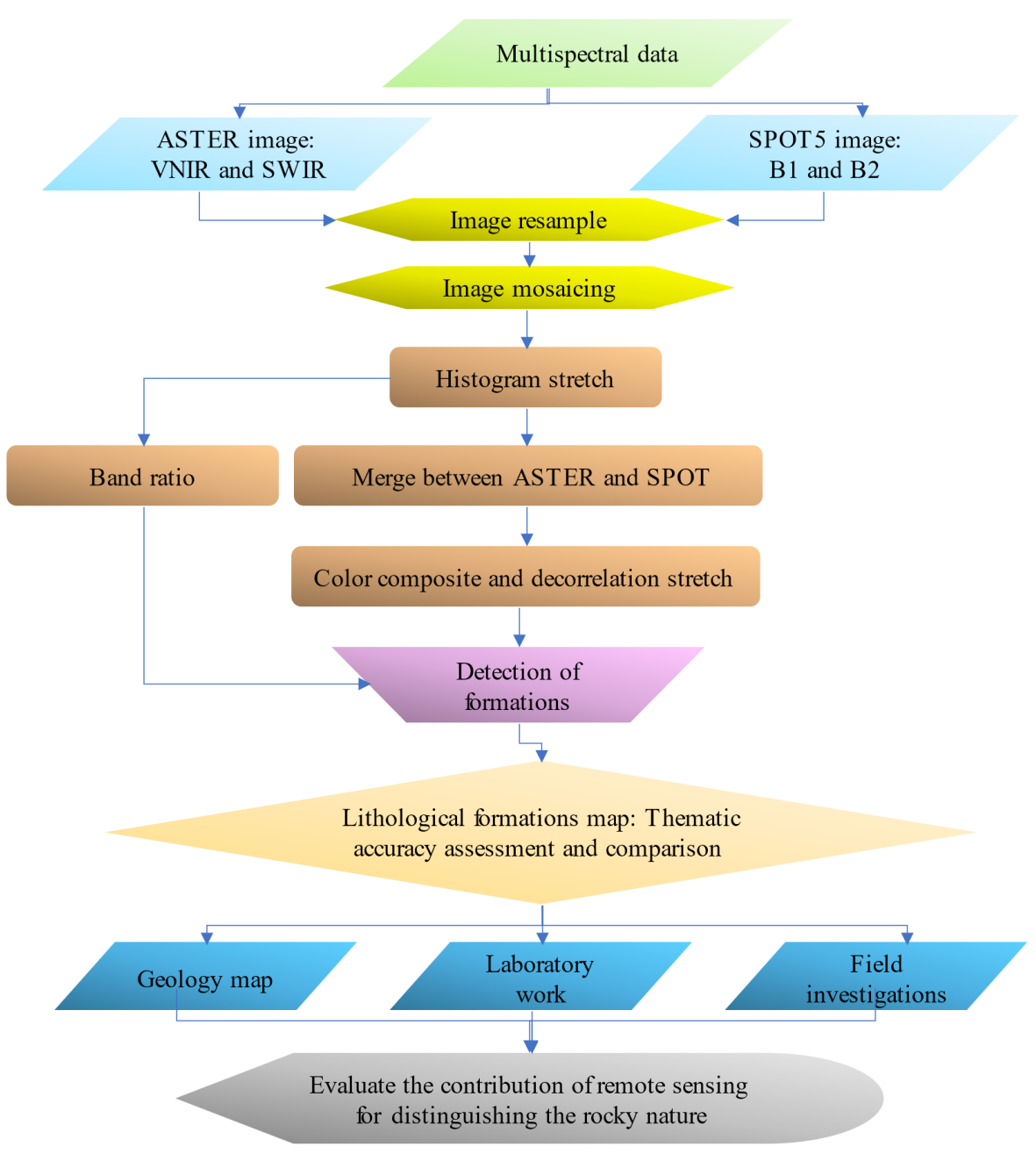

Figure 3. Flow chart of the study methodology.

Table 1. Raster datasets used for the study.

\begin{tabular}{cccccc}
\hline Satellite & Bands & Date & Resolution $(\mathrm{m})$ & Path & Raw \\
\hline ASTER & 14 & 1 March 2007 & $15-30-90$ & --- & --- \\
ASTER & 14 & 3 March 2006 & $15-30-90$ & --- & --- \\
SPOT-5 & 4 & 2005 & $2.5-5-10-20$ & 135 & 302 \\
\hline
\end{tabular}

Table 2. Spot-5 bands specifications.

\begin{tabular}{|c|c|c|c|c|c|}
\hline Bands & Label & Wavelength $(\mu \mathrm{m})$ & Resolution (m) & Nadir or Backward & Description \\
\hline B1 & Pan $2 \times 5$ m scene & $0.480-0.710$ & 2.5 & Nadir & Panchromatic \\
\hline B1 & Pan & $0.480-0.710$ & 5 & Nadir & Panchromatic \\
\hline B2 & G & $0.500-0.590$ & 10 & Nadir & Green \\
\hline B3 & $\mathrm{R}$ & $0.610-0.680$ & 10 & Nadir & Red \\
\hline B4 & IR & $0.780-0.890$ & 10 & Nadir & Infra-Red (IR) \\
\hline B5 & SWIR & $1.580-1.750$ & 20 & Nadir & Shortwave IR \\
\hline
\end{tabular}


Table 3. ASTER bands specifications.

\begin{tabular}{cccccc}
\hline Bands & Label & Wavelength $(\mu \mathrm{m})$ & $\begin{array}{c}\text { Resolution } \\
(\mathrm{m})\end{array}$ & $\begin{array}{c}\text { Nadir or } \\
\text { Backward }\end{array}$ & Description \\
\hline B1 & VNIR_Band1 & $0.520-0.600$ & 15 & Nadir & Visible green/yellow \\
\cline { 5 - 6 } B2 & VNIR_Band2 & $0.630-0.690$ & 15 & Nadir & Visible red \\
\cline { 4 - 5 } B3N & VNIR_Band3N & $0.760-0.860$ & 15 & Nadir & Near infrared \\
B3B & VNIR_Band3B & $0.760-0.860$ & 15 & Backward & \\
B4 & SWIR_Band4 & $1.600-1.700$ & 30 & Nadir & Short-wave infrared \\
B5 & SWIR_Band5 & $2.145-2.185$ & 30 & Nadir & \\
B6 & SWIR_Band6 & $2.185-2.225$ & 30 & Nadir & \\
B7 & SWIR_Band7 & $2.235-2.285$ & 30 & Nadir & \\
B8 & SWIR_Band8 & $2.295-2.365$ & 30 & Nadir & \\
B9 & SWIR_Band9 & $2.360-2.430$ & 30 & Nadir & \\
B10 & TIR_Band10 & $8.125-8.475$ & 90 & Nadir & Long-wave infrared \\
B11 & TIR_Band11 & $8.475-8.825$ & 90 & Nadir & or thermal IR \\
B12 & TIR_Band12 & $8.925-9.275$ & 90 & Nadir & \\
B13 & TIR_Band13 & $10.250-10.950$ & 90 & Nadir & \\
B14 & TIR_Band14 & $10.950-11.650$ & 90 & Nadir & \\
\hline & & & & & \\
\end{tabular}

spectral bands, which provide information to determine the boundaries between different lithological types.

The 14 bands of ASTER sensor cover a wide spectral range, which have a specification from visible to thermal infrared or high spatial, spectral, and radiometric resolution (Figure 1). An additional backward-looking near infra-red band provides stereo coverage as well. Spatial resolution of this sensor varies with wavelength: $15 \mathrm{~m}$ in the Visible near Infra-Red (VNIR) telescope, $30 \mathrm{~m}$ in Shortwaves Infrared (SWIR) telescope, and $90 \mathrm{~m}$ in Thermal Infra-Red (TIR) telescope. Each ASTER scene covers an area of about $60 \mathrm{~km} \times 60 \mathrm{~km}$. Six spectral bands of the SWIR telescope (ASTER) have been designed to measure the reflected solar radiation in order to distinguish between the elements like $\mathrm{Al} \mathrm{OH}$, $\mathrm{Fe}, \mathrm{Mg} \mathrm{OH}$ and $\mathrm{Si} \mathrm{O} \mathrm{H}$ as well as the $\mathrm{CO} 3$ absorption features [33] in [16].

\subsection{Image Enhancement Techniques}

The following subsections are summarized from the software built-in manual of the ERDAS IMAGINE version 2020, which was used to generate all of the scenes, provided in this study. The provided charts in this subsection are also drawn by built-in software package with ERDAS IMAGINE.

\subsubsection{Mosaic of ASTER}

MosaicPro software package within the ERDAS IMAGINE was applied to join georeferenced images and form a larger image or a set of images (these mosaicked project files are named with a mop file extension). The input images 
must all contain map and projection information and have the same number of layers. They do not need to be in the same projection or have the same pixel cell sizes. Calibrated input images are also supported. Vertical datums and units must match in all of terrain input data in order to mosaic terrain data properly. Therefore, two ASTER scenes were mosaiced in order to fit with the SPOT data, in order to perform the merging of the two data. However, the next enhancement step, performed in this study is histogram stretching before resolution merge.

\subsubsection{Resolution Merge}

It integrates imagery of different spatial resolutions (pixel size). Since higher resolution imagery is generally single band (for example SPOT Panchromatic 2.5 $\mathrm{m}$ data), while multispectral imagery generally has the lower resolutions (for example ASTER $15 \mathrm{~m}$ ), these techniques are often used to produce high resolution multispectral imagery. This improves the interpretability of the data by having high resolution information which is also in color. Resolution Merge offers three techniques: Multiplicative, Principal Components, and Brovey Transform. The Multiplicative is based on simple arithmetic integration of the two raster sets. Brovey Transform uses a ratio algorithm to combine the images. Principal Components merge operates on PC-1 rather than the input raster image. Figure 4 shows the flow chart of the PC component merge that was used in this study.

\subsubsection{Decorrelation Stretch and Band Ratio}

It stretches the principal components of an image, rather than the image itself. Perform a contrast stretch on the imagery to decorrelate the bands and thereby produce a more "contrasty" and strongly colored output image using the Principal Components transformation. Figure 5 shows the processes performed by ERDAS IMAGINE for decorrelation stretch enhancement. Band ratio is performed by simple image algebra operations on three input files, in which two high values bands are added to each other, divided by low value band (Figure 6).

\section{Results}

Several image processes were performed on the study area. Figure 7 is from ASTER satellite, and the image combination is shown in Table 4. The image shows the rocks clearly and distinguished them better than ETM images with the combination (741) in (RGB) after histogram stretching. In this study merging band 2 of SPOT 5 with the ASTER images in the combination of (841) in (RGB) has also been applied (Figure 8). It showed quartz veins and ultramafic rocks clearly from other units, and Table 5 shows resolution of histogram stretching. Decorrelation stretch of the merged images was also conducted, and it distinguished several formations of the metamorphic meta-basalt (Figure 9). The last type of image processes, conducted in this study is band ratio, in which two types of ratio were performed. Figure 10 shows complex band ratio of [(band 2 + band 5)/band 7)] of ASTER. This ratio turn on the ultramafic and mafic rocks, 


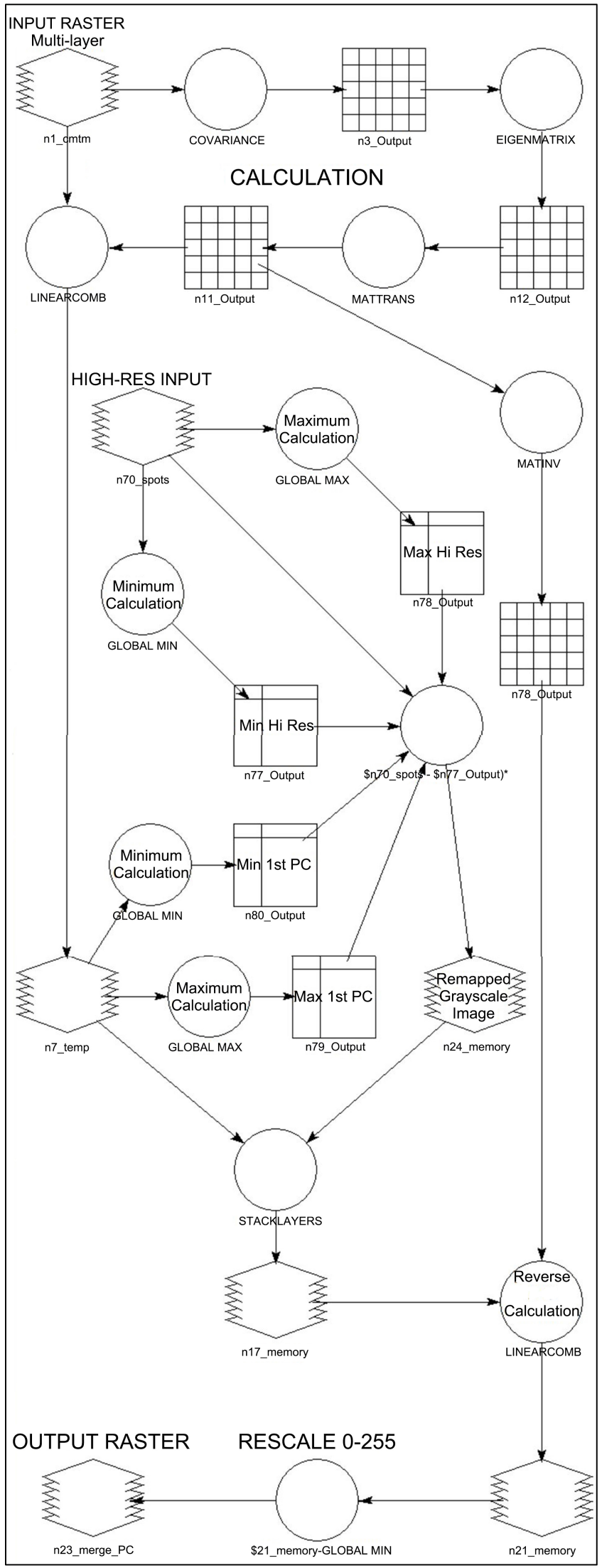

Figure 4. Flow chart of merging. 


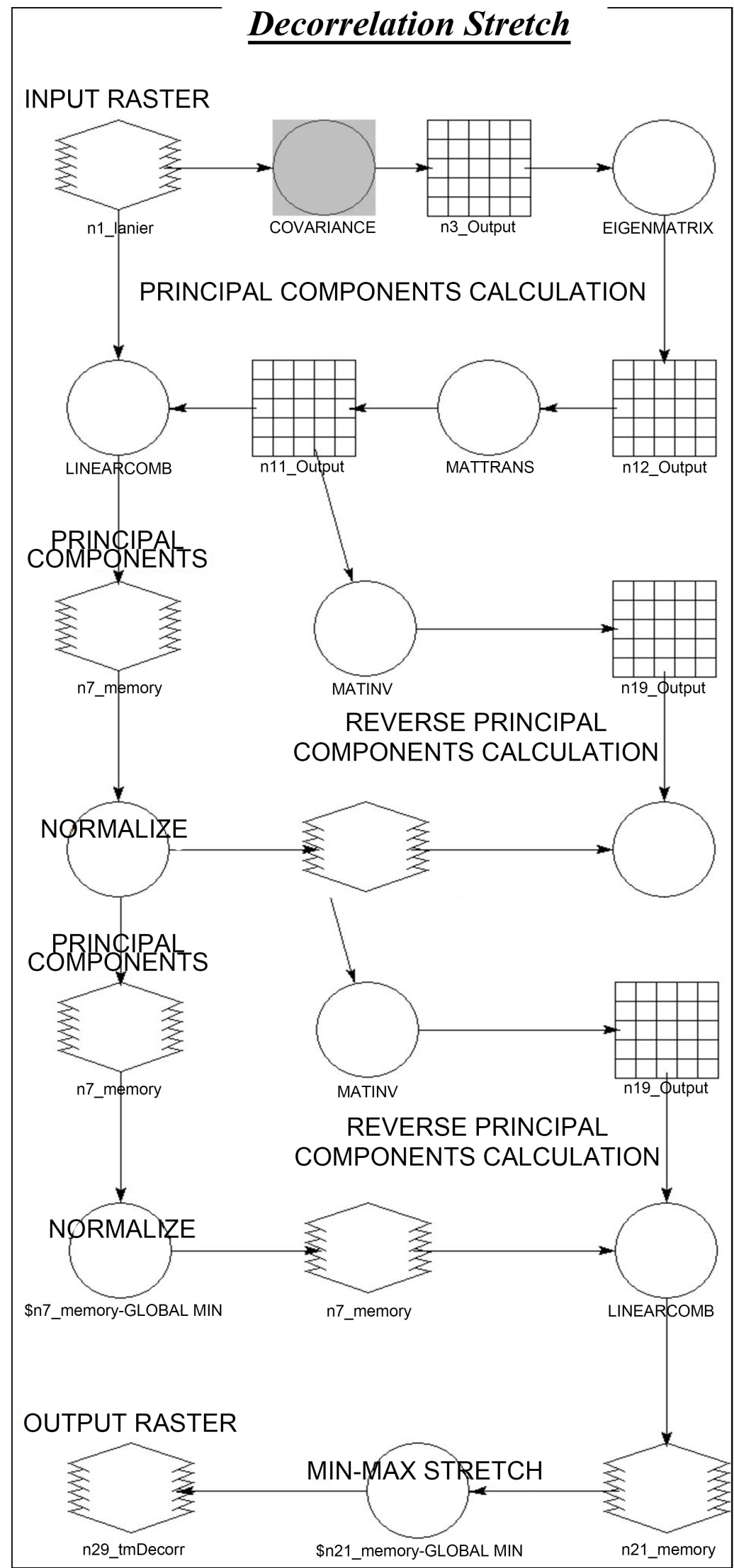

Figure 5. Flow chart of decorrelation stretch. 


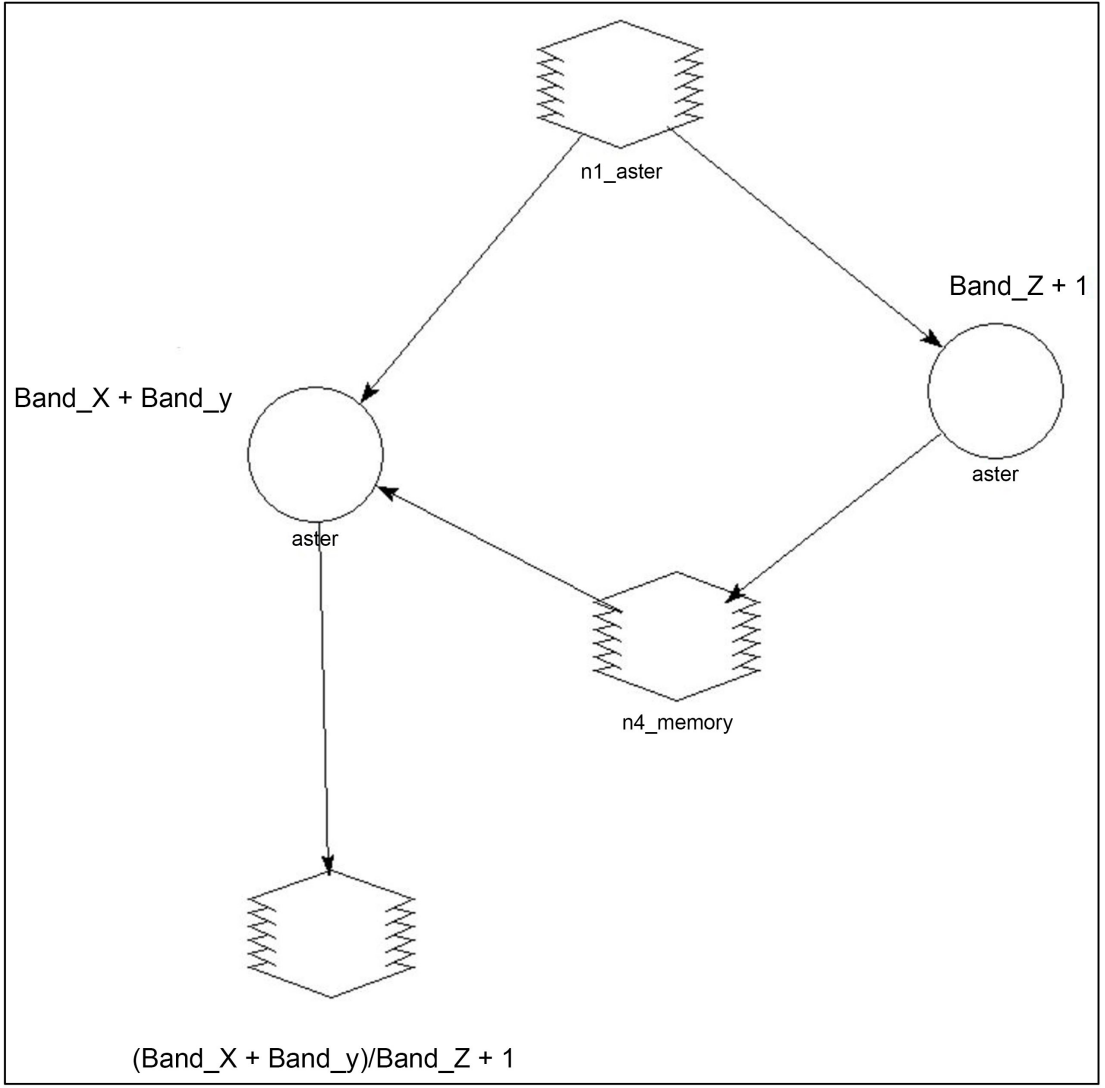

Figure 6. Flow chart of band ratio.

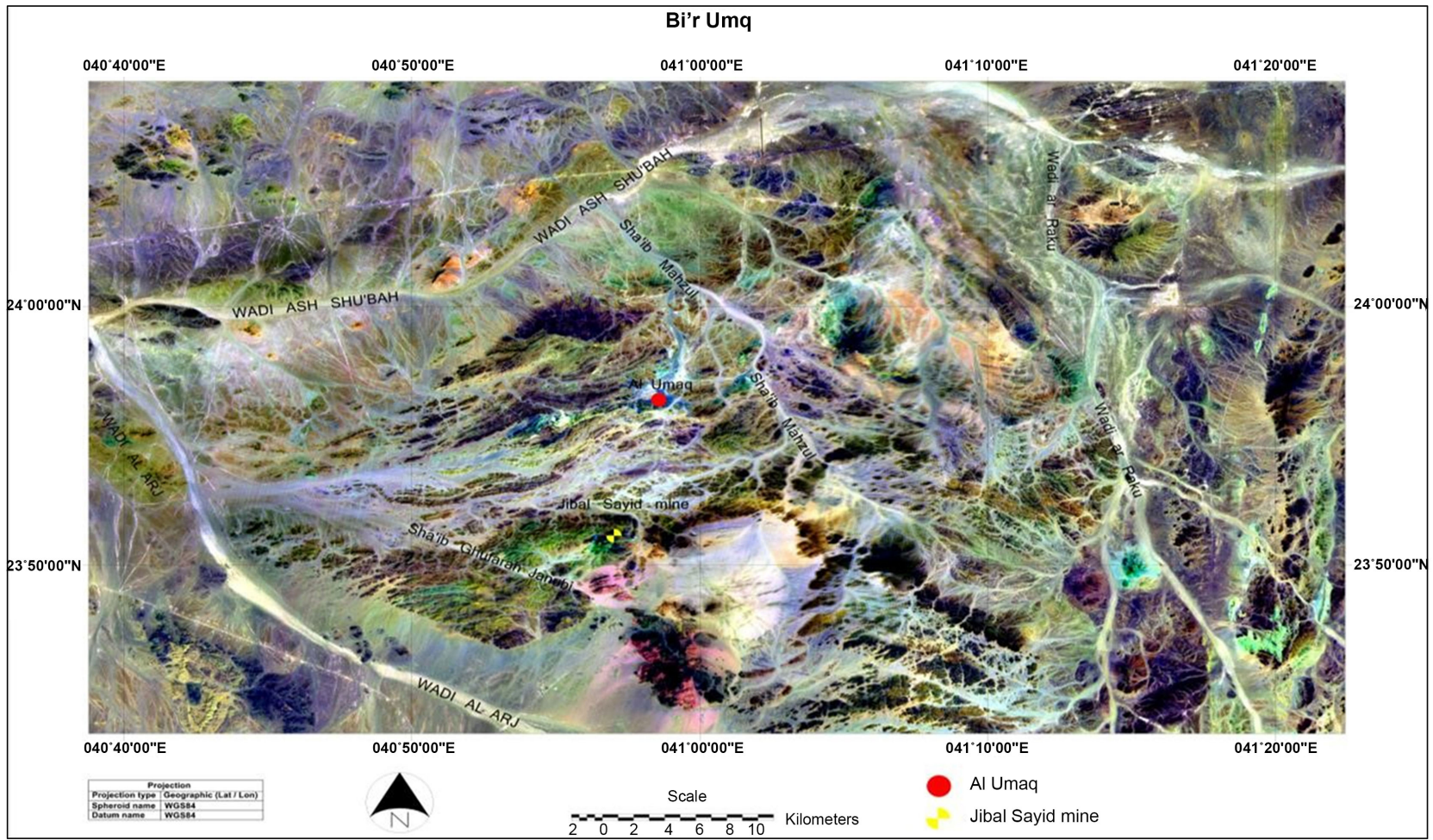

Figure 7. ASTER false color composite image (RGB bands 841). This image distinguishes the ultramafic rock units from the surrounding rock units. 


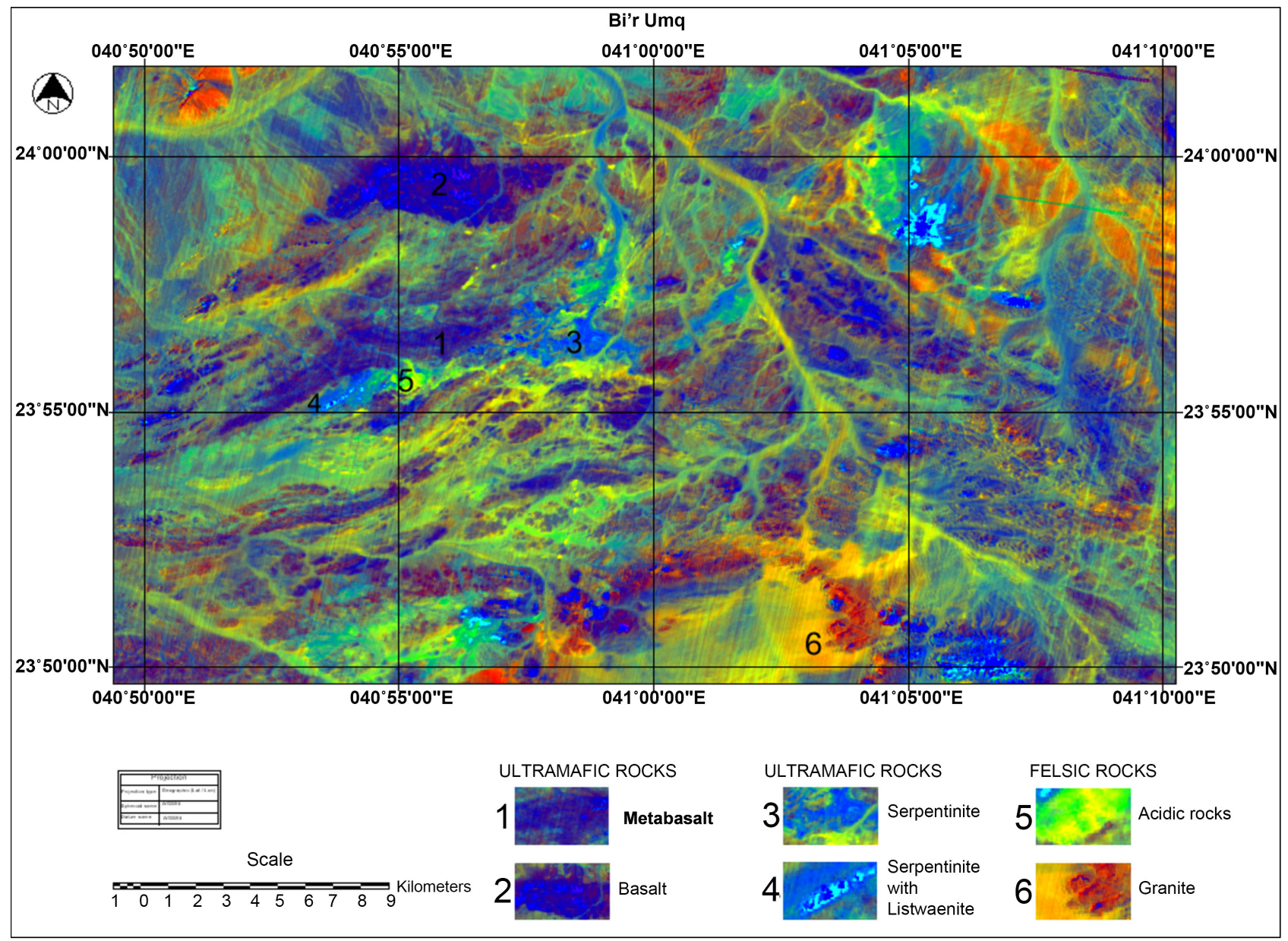

Figure 8. ASTER false color composite image (RGB bands 841) merged with band 2 of SPOT 5.

Table 4. Shows the histogram stretch resolution pairs for the three bands of ASTER image in Figure 1.

\begin{tabular}{cccccc}
\hline $\begin{array}{c}\text { Composit } \\
\text { color }\end{array}$ & Bands & $\begin{array}{c}\text { Min. resolution pair before } \\
\text { stretching }\end{array}$ & $\begin{array}{c}\text { Min. resolution pair in the } \\
\text { image stretched to } 0\end{array}$ & $\begin{array}{c}\text { Max. resolution pair in the image } \\
\text { stretched to 255 }\end{array}$ & $\begin{array}{c}\text { Max. resolution before } \\
\text { stretching }\end{array}$ \\
\hline Red & 8 & $0-0$ & $117-0$ & $193-255$ & $255-255$ \\
Green & 4 & $0-0$ & $99-0$ & $186-255$ & $255-255$ \\
Blue & 1 & $0-0$ & $70-0$ & $120-255$ & $255-255$ \\
\hline
\end{tabular}

Table 5. Shows the minimum and maximum pairs used in histogram stretching of image in Figure 8 before and after stretching.

\begin{tabular}{cccccc}
\hline $\begin{array}{c}\text { Composite } \\
\text { color }\end{array}$ & Bands & $\begin{array}{c}\text { Min. resolution pair before } \\
\text { stretching }\end{array}$ & $\begin{array}{c}\text { Min. resolution pair in the } \\
\text { image stretched to } 0\end{array}$ & $\begin{array}{c}\text { Max. resolution pair in the } \\
\text { image stretched to 255 }\end{array}$ & $\begin{array}{c}\text { Max. resolution before } \\
\text { stretching }\end{array}$ \\
\hline Red & 8 & $0-0$ & $143-0$ & $184-255$ & $255-255$ \\
Green & 4 & $0-0$ & $135-0$ & $171-255$ & $255-255$ \\
Blue & 1 & $0-0$ & $59-0$ & $90-255$ & $255-255$ \\
\hline
\end{tabular}

and turn off all other rock units. Figure 11 shows complex band ratio of ((band $1+$ band 2)/band 4) of ASTER, which shows the meta-basalt very clear from other units. Experimental lab studies measuring and comparing the spectral 


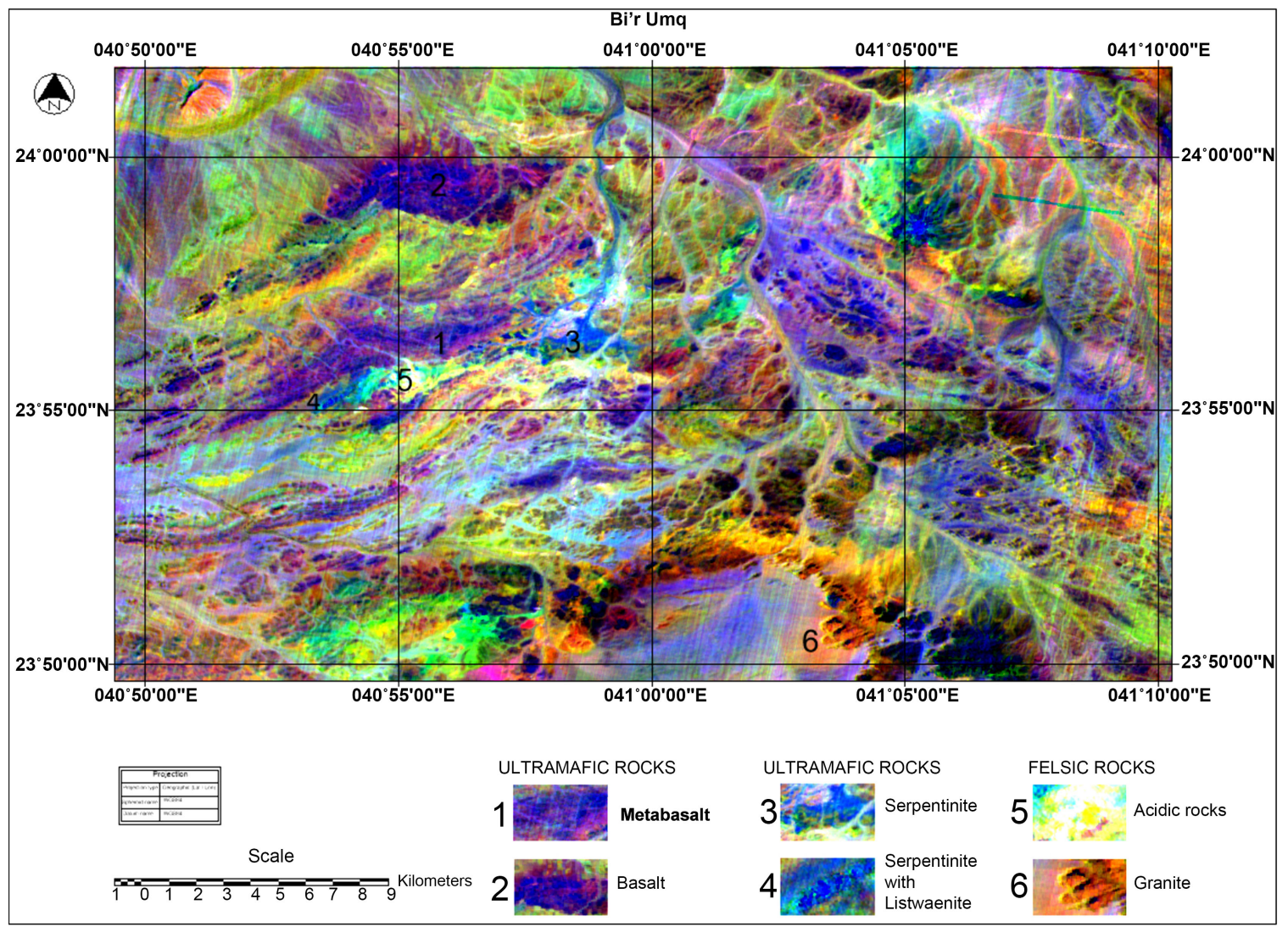

Figure 9. Decorrelation stretch image of the ASTER false color composite image (RGB bands 841), merged with the SPOT 5 band 1 image.

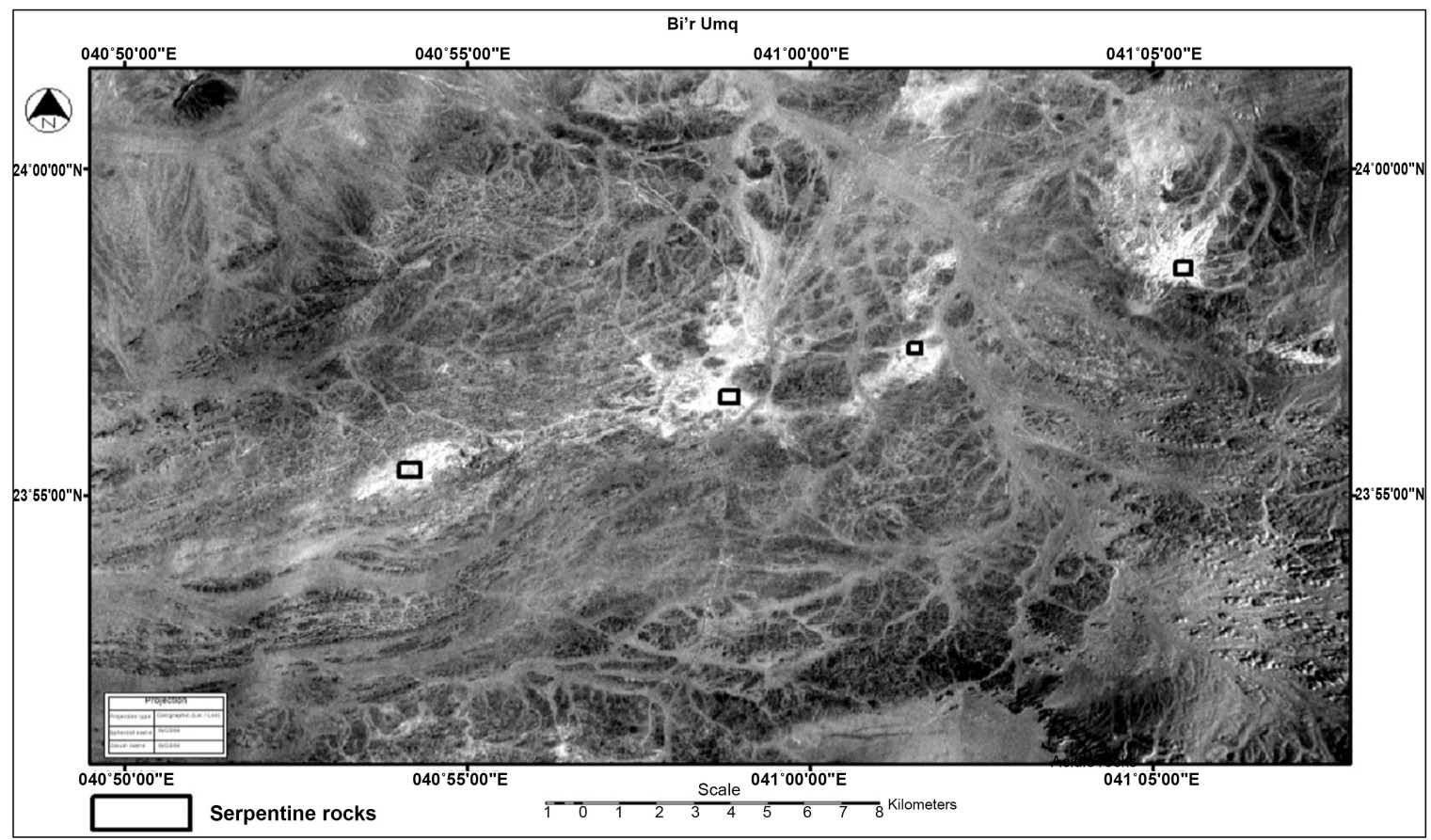

Figure 10. ASTER band ratio image of (band $2+$ band 5)/band 7 after applying histogram stretch, where $0=93$ for the minimum and $255=151$ for the maximum. This image differentiates the serpentine in the white colour from other rock units. 


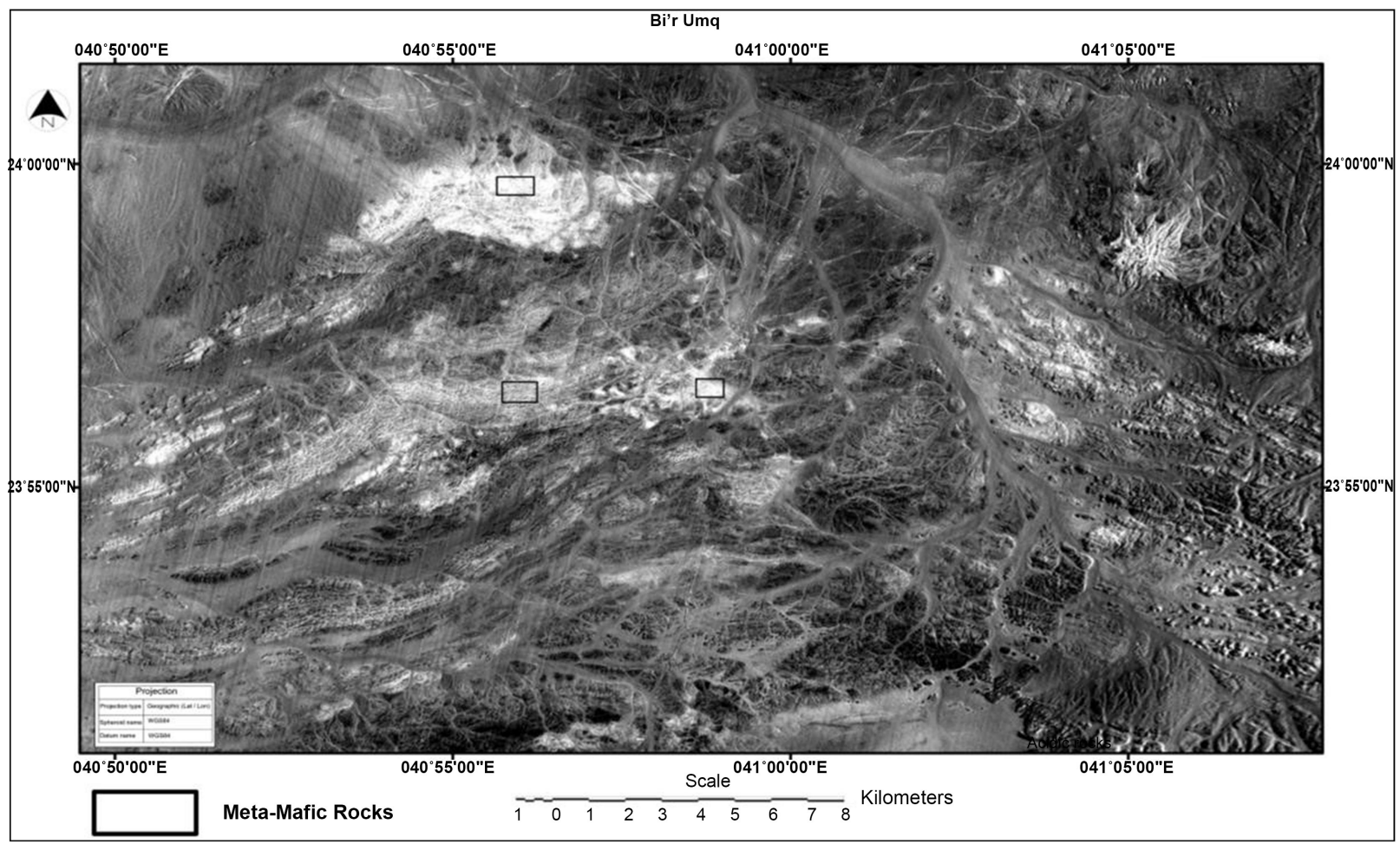

Figure 11. ASTER band ratio image of (band $1+$ band 2)/band 4 after applying histogram stretch, in which $0=67$ for the minimum and $255=124$ for the maximum. This image shows the mafic and ultramafic rocks as light colours.

reflectance, spectral absorption, and spectral ratio features with chemical contents of the rock samples from the study area should be conducted to enhance the capacity of remote sensing to differentiate mineralized rocks from barren rocks. The obtained parameters from the experimental studies are then used to produce remote sensing imageries that predict the mineralized zones from non-mineralized zones [34].

This image is false colors (Figure 7), as most of the satellites take pictures in ranges that the human eye cannot see, and if a person is provided with means to help him vision in these spectral ranges, he can see the rocks in nature with the same colors that appear in the processed images. When using the visible spectrum band, satellite images appear in the same colors that are seen in nature, and in this case it is called the image with true colors, as it displays the colors in the image as we see it with the naked eye. Although most of the rocks in the study area are ophiolite, the channels (RGB bands 841) highlight high differences in distinguishing between different types of rocks, most of the mafic are dark in color in general, while acidic ones such as granite take pink and gradually to orange and then yellow then white, and in this figure, granodiorite appeared in darker color at the bottom of the image. As for the serpentine rocks, they take a light blue color and gradient to light green. This description in general highlights a large difference in the various rocks.

The second channel (band 2) from the satellite image (SPOT 5) is combined with the sensor images (ASTER) for the channels (RGB bands 841) to take ad- 
vantage of multi-spectral imagery in the sensor (ASTER) and high-resolution image from the satellite image (SPOT 5). To obtain a new, high-resolution MERGE image with multi-spectral band. The results were excellent, as a new image with high discrimination was obtained in the types of rocks, better than the image in (Figure 8).

In Figure 9, this image the RATIO technique was used to determine the position of the serpentine rocks in the region, showing the serpentine areas in white. In order to raise the values of serpentine rocks, the two channels (band $2+$ band 5) were collected and divided by channel 7 because the values of serpentine are low and the other rocks are high.

(RATIO) technique was used in this image to determine the position of the serpentine rocks in the region, so the image shows the serpentine regions in white, then the two channels (band $1+$ band 2 ) were collected to raise the values of the rocks (the mafic and ultramafic rocks), which contain dark minerals such as iron in low quantities and split them by channel band 4 (the mafic and ultramafic rocks) (Figure 10 and Figure 11).

\section{Lithologic Units}

Collected samples across the main E-W direction of faulted and folded rocks were prepared into thin-sections for microscopic studies to show mineralogical and petrologic make-up of the study area [34]. The study area is characterized by several rock types such as serpentine, listwaenite and layered meta-volcanic rocks such as basalt and andesite. Figure 12 shows the serpentine rocks (dark green), faulted and foliated in association with the listwaenite which is by product of serpentines that form after hydrothermal alteration.

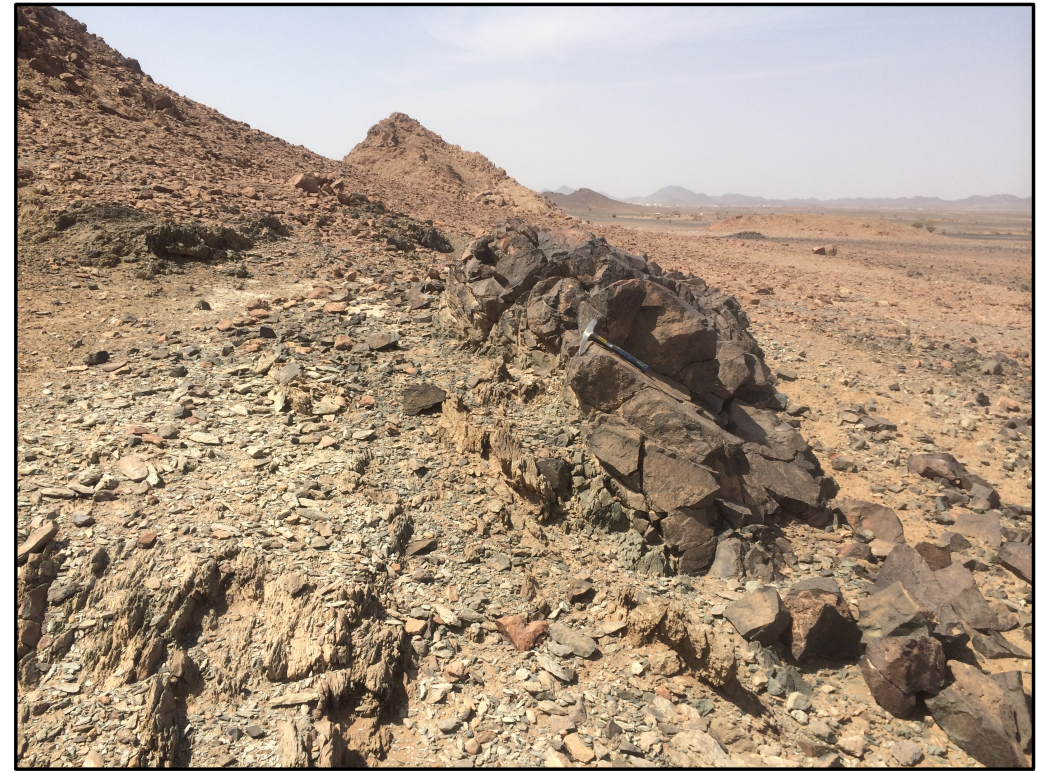

Figure 12. Highly foliated serpentinite has greenish colour, surrounded by altered serpentinite that turned completely into reddish brown listwaenite, view looking W. These rocks are part of the ultramafic sequence of Bir Umq ophiolite. Hammer is for scale. 


\section{Discussion}

Several combinations were tested to distinguish the ophiolite rocks in the ASTER imageries. The best combination that has been given best results is the 841 in the RGB combination. This false colour composite imagery shows the mafic and ultramafic rocks in dark violet colour, where the felsic rocks appeared in the pink colour. However, this imagery is affected by shadow of outcrops, and the rocks colours are not homogenous. In order to make them homogeneous merging technique have been used, to get advantage of the high resolution of the Spot 5 data, which has $2.5 \mathrm{~m}$ resolution. This image as shown in Figure 7 has homogenized the colours of mafic and ultramafic rocks versues the felsic rocks. The mafic rocks such as basalt is clearly appearing by the blue pink colour, while the listawenite have the blue sky colour. Moreover, the felsic granitic rock have taking the red fire colour, where the fine-grained felsic rocks such as the rhyolite have appeard with yellow colour and light green in the decorrelation stretch. Therefore, there are matching with the geologic mapping. The merged imagery in Figure 8 gives colour of the rocks and weathered sediments from the same rocks as shown by the wadi sediments. Therefore, the decorrelation stretch imagery of Figure 8 was processed and produced to have better view of the rock units. The three imagaries have important results showing rock units from different angles. Also, they are helpful in geologic mapping and economic geology studies. The image rationing processing is important for its distinguishing the mafic and ultramafic rocks from other rocks, which shows light grey colour, compared to other rock. These results therefore, have confirmed the results. After that a contrast stretch was performed to increase the intolerance of the mafic and ultramafic rocks.

\section{Conclusion}

This study highlights the value of remote sensing for geological mapping in arid zones. On the one hand, this tool is effective in locating a priori the outcrops to be visited by the geologist, thus optimising field campaigns. On the other hand, satellite imagery offers a fast and accurate means of mapping surface structures. ASTER and SPOT multispectral images can potentially be used to detect and distinguish ophiolitic rocks. The results also confirm the potential of the methods to be used in geological exploration work where the location of ophiolitic rocks and alteration zones is an important issue for the discovery of new deposits. The TIR bands detect the emission of EMR from rocks, while the VNIR bands measure the reflection of EMR from rocks. TIR bands, which are considered useful tools for distinguishing different geological horizons of the oceanic and continental crusts. Band ratios were used to distinguish the various lithological types. It is hoped that this research will inspire further work in exploiting for example hyper-spectral data for the differentiation of a wider variety of lithological components. In general, the quality of the results obtained with the ASTER spectral range combined with the SPOT images represents an advantage 
for lithological and mineralogical mapping on a regional scale, as well as for the production of a reference document for the identification of areas of discontinuities between geological sheets, which deserve particular updates and/or verifications in the field. The approach of this study can be applied to other areas where similar exposures are expected, to improve the geological mapping of drylands.

\section{Conflicts of Interest}

The authors declare no conflicts of interest regarding the publication of this paper.

\section{References}

[1] Dilek, Y. and Ahmed Z. (2003) Proterozoic ophiolites of the Arabian Shield and their significance in Precambrian tectonics. In: Dilek, Y. and Robinson, P.T., Eds., Ophiolites in Earth History, Geological Society of London, London, 717 p. https://doi.org/10.1144/GSL.SP.2003.218.01.33

[2] Ahmed, Z. and Hariri, M.M. (2008) Neoproterozoic Ophiolites as Developed in Saudi Arabia and Their Oceanic and Pericontinental Domains. Arabian Journal for Science and Engineering, 33, 17-54.

[3] Baghdadi, N., Grandjean, G., Lahondère, D., Paillou, P. and Lasne, Y. (2005) The Contribution of Radar Satellite Imagery to Geological Exploration in Arid Areas. Comptes Rendus Geoscience, 337, 719-728.

https://www.sciencedirect.com/science/article/abs/pii/S1631071305000490 https://doi.org/10.1016/j.crte.2005.03.003

[4] Luca, S., Uyttendaele, M. and Ozer, A. (1988) Télédétection Géologique et Géomorphologique dans le secteur de Hamoir. Bulletin de la Société belge de Géologie, 191-197.

[5] Emran, A., Hakdaoui, M. and Chorowicz, J. (1996) Contribution des signatures spectrales et des textures a la cartographie géologique par classification dirigée d'image du HRV-XS de SPOT en régime désertique : exemple du secteur minier de Zgounder (Anti-Atlas, Maroc). International Journal of Remote Sensing, 17, 863-877. https://doi.org/10.1080/01431169608949052

[6] El Qayedy, J., Taj-Edinne, K., Bonn, F., Chikhaoui, M. and Witam, O. (2006) Caractérisation Lithologique du Haut Atlas Marocain à l'aide des données d'ASTER et de mesures spectrales de terrain. Télédétection, 6, 153-175.

https://www.researchgate.net/publication/249008587_Caracterisation_lithologique du_Haut_Atlas_marocain_a_l'aide_des_donnees_ASTER_et_des_mesures_spectral es_de_terrain

[7] Hubbard, B., Crowley, J. and Zimbelman, D. (2003) Comparative Altération Minerai Mapping Using Visible to Shortwave Infrared (0,4-2,4)im) Hyperion, ALI and ASTER Imagery. IEEE Transactions on Geoscience and Remote Sensing, 41, 1401-1410. https://doi.org/10.1109/TGRS.2003.812906

[8] Rowan, L.C. and Mars, J.C. (2003) Lithologie Mapping in the Mountain Pass, Califomia Area Using Advanced Spacebome Thermal Emission and Reflection Radiometer (ASTER) Data. Remote Sensing of Environment, 84, 350-366. https://doi.org/10.1016/S0034-4257(02)00127-X

[9] Hook, S., Dmochowski, J., Howard, K., Rowan, L., Karlstrom, K. and Stock, J. (2005) Mapping Variations in Weight Percent Silica Measured from Multispectral Thermal Infrared Imagery-Examples from the Hiller Mountains, Nevada, USA 
and Très Virgenes-La Reforma, Baja California Sur, Mexico. Remote Sensing of Environment, 95, 273-289. https://doi.org/10.1016/j.rse.2004.11.020

[10] Hewson, R., Cudahy, T., Mizuhiko, S., Ueda, K. and Mauger, A. (2005) Seamless Geological Map génération Using ASTER in the Broken Hill-Curnamona Province of Australia. Remote Sensing of Environment, 99, 159-172. https://doi.org/10.1016/j.rse.2005.04.025

[11] Ninomiya, Y., Bihong, H. and Cudahy, T. (2005) Detecting Lithology with Advanced Spacebome Thermal Emission and Reflection Radiometer (ASTER) Multispectral Thermal Infrared 'Radiance-at-Sensor' Data. Remote Sensing of Environment, 99, 50-61. https://doi.org/10.1016/j.rse.2005.06.009

[12] Hubbard, B., Rowan, L., Dusel-Bacon, C. and Eppinger, R. (2007) Geologic Mapping and Mineral Resource Assessment of the Healy and Talkeetna Mountains Quadrangles, Alaska Using Minimal Cloud-and Snow Cover ASTER Data. Open-File Report of U. S. Geological Survey, Virginia, 22 p. https://doi.org/10.3133/ofr20071046

[13] Zhang, X. and Pazner, M. (2007) Comparison of Lithologie Mapping with ASTER, Hyperion and ETM Data in the Southeastem Chocolaté Mountains, USA. Photogrammetric Engineering \& Remote Sensing, 73, 555-561. https://doi.org/10.14358/PERS.73.5.555

[14] Moore, P., Rastmanesh, P., Asadi, H. and Modabberi, S. (2008) Mapping Mineralogical Altération Using Principal-Component Analysis and Matched Filter Processing in the Tabak Area, North-West Iran, from ASTER Data. International Journal of Remote Sensing, 20, 2851-2867. https://doi.org/10.1080/01431160701418989

[15] Rowan, L. and Mars, J. (2001) Advances in Lithologie Mapping by Using Optical Remote Sensing Meausurements. Geological Society of America, Annual Meeting, Abstracts with Programs, p. 347.

[16] Matar, S.S. and Bamousa, A.O. (2013) Integration of the ASTER Thermal Infra-Red Bands Imageries with Geological Map of Jabal Al Hasir Area, Asir Terrane, the Arabian Shield. Journal of Taibah University for Science, 7, 1-7. https://doi.org/10.1016/j.jtusci.2013.01.001

[17] Gomez, C., Delacourt, C., Allemand, P., Ledru, P. and Wackerle, R. (2005) Using ASTER Remote Sensing Data Set for Geological Mapping, in Namibia. Physics and Chemistry of the Earth, 30, 97-108. https://doi.org/10.1016/j.pce.2004.08.042

[18] Rowan, L.C., Mars, J.C. and Simpson, C.J. (2005) Lithologic Mapping of the Mordor, NT, Australia Ultramafic Complex by Using the Advanced Spaceborne Thermal Emission and Reflection Radiometer (ASTER). Remote Sensing of Environment, 99, 105-126. https://doi.org/10.1016/j.rse.2004.11.021

[19] Qari, M.H.T., Madani, A.A., Matsah, M.I.M. and Hamimi, Z. (2008) Utilization of ASTER and Landsat Data in Geologic Mapping of Basement Rocks of Arafat Area, Saudi Arabia. The Arabian Journal for Science and Engineering, 33, 99-115. http://www.academia.edu/29990836/Utilization_of_Aster_and_Landsat_data_in_ge ologic_mapping_of_basement_rocks_of_Arafat_Area_Saudi_Arabia

[20] Pour, B.A., Hashim, M. and Marghany, M. (2011) Using Spectral Mapping Techniques on Short Wave Infrared Bands of ASTER Remote Sensing Data for Alteration Mineral Mapping in SE Iran. International Journal of the Physical Sciences, 6, 917-929. https://academicjournals.org/article/article1380803930_Pour\%20et\%20al.pdf

[21] Pour, B.A. and Hashim, M. (2012) Identifying Areas of High Economicpotential Copper Mineralization Using ASTER Data in Urumieh-Dokhtar Volcanic Belt, Iran. Advances in Space Research, 49, 753-769. 
https://doi.org/10.1016/j.asr.2011.11.028

[22] Haldar, S.K. (2018) Chapter 15-Mineral Exploration: Case Histories. In: Haldar, S.K., Ed., Mineral Exploration, 2nd Edition, Elsevier, Amsterdam, 313-352. https://doi.org/10.1016/B978-0-12-814022-2.00015-0

[23] Testa, F.J., Villanueva, C., Cooke, D.R. and Zhang, L. (2018) Lithological and Hydrothermal Alteration Mapping of Epithermal, Porphyry and Tourmaline Breccia Districts in the Argentine Andes Using ASTER Imagery. Remote Sensing, 10, 203. https://www.mdpi.com/2072-4292/10/2/203 https://doi.org/10.3390/rs10020203

[24] Johnson, P.R., Abdelsalam, M. and Stern, R.J. (2003) The Bir Umq-Nakasib Shear zone: Geology and Structure of a Neoproterozoic Suture in the Northern East African Orogen, Saudi Arabia and Sudan: Saudi Geological Survey Technical Report. 33p.

[25] Delfour, J. (1981) Explanatory Notes to the Geologic Map of the Al Hissu Quadrangle, Scale 1:250,000 Sheet 24E, Kingdom of Saudi Arabia. Saudi Arabian Deputy Ministry for Mineral Resources Geoscience Map GM, 58, p. 47.

[26] Kemp, J., Gros, Y. and Prain, J.P. (1982) Explanatory Notes to the Geologic Map of the Mahd Adh Dhabab Quadrangle, 1:250,000, Sheet 23E, Kingdom of Saudi Arabia. Saudi Arabian Deputy Ministry for Mineral Resources Geologic Map GM, 64, p. 39.

[27] Al-Rehaili, M.H. and Warden, A.J. (1980) Comparison of the Bir Umq and Hamdah Ultrabasic Complexes, Saudi Arabia. Institute of Applied Geology Bulletin, 3, 143-156. https://doi.org/10.1016/B978-0-08-024481-5.50018-2

[28] Al-Shanti, A.M.S. (1993) Geology of the Arabian Shield, Jeddah King Abdul Aziz University. Scientific Publication Center, Jeddah, 196 p.

[29] Johnson, P.R. and Woldehaimanot, B. (2003) Development of the Arabian-Nubian Shield: Perspectives on Accretion and Deformation in the Northern East African Orogen and the Assembly of Gondwana. Geological Society London Special Publications, 206, 289-325. https://doi.org/10.1144/GSL.SP.2003.206.01.15

[30] Johnson, P.R., Kattan, F.H. and Al-Saleh, A.M. (2004) Neoproterozoic Ophiolites in the Arabian Shield: Field Relations and Structure. In: Kusky, T.M., Ed., Precambrian Ophiolites and Related Rocks, Elsevier, Developments in Precambrian Geology, Amsterdam, 129-162. https://doi.org/10.1016/S0166-2635(04)13004-1

[31] Hargrove, U.S., Stern, R.J., Griffin, W.R., Johnson, P.R. and Abdelsalam, M.G. (2006) From Island Arc to Craton: Timescales of Crustal Formation along the Neoproterozoic Bir Umq Suture Zone. Kingdom of Saudi Arabia: Saudi Geological Survey Technical Report SGS-TR-2006-6, 69 p.

[32] Hargrove, U.S., Stern, R.J., Kimura, J.I., Manton, W.I. and Johnson, P.R. (2006) How Juvenile Is the Arabian-Nubian Shield? Evidence from $\mathrm{Nd}$ Isotopes and Pre-Neoproterozoic Inherited Zirocn in the Bir Umq Suture Zone, Saudi Arabia. Saudi Geological Survey Open-File Report SGS-OF-2006-8, 55p.

[33] Abrams, M. and Hook, S.J. (1995) Simulated ASTER Data for Geologic Studies. IEEE Transactions on Geoscience and Remote Sensing, 33, 692-699. https://doi.org/10.1109/36.387584

[34] Matar, S.S., Siddiqui, A.A. and Bamousa, A.O. (2018) Metallogenesis of the Bir Umq Ophiolite, Southeast Al Madinah Al Munawarrah, Western Saudi Arabia. Remote sensing, Mineralogical, Petrological, and Geochemical Studies. Saudi Geological Survey Technical Report, SGS-TR, 36p. 